\title{
Study on the Reference Effect and Practice Research of Folk Art to Modern Art Design
}

\author{
Ronghui Wang \\ Fuzhou University of International Studies and Trade, Fuzhou, Fujian350202, China
}

Keywords: Folk Art, Art Design, Reference Effect, Practice

\begin{abstract}
Based on the basic characteristics and present situation analysis of folk art and modern art design, we explore the cultural root of folk art in traditional art thoroughly, and interpret its academic significance and theoretical contribution to the development of modem art design to build the reference relationship between the two in the paper. Based on this, we discuss the application, practice of local folk art in modern art design and other related problems in the paper.
\end{abstract}

\section{Introduction}

\subsection{The Basic Interpretation of Folk Art}

There is no doubt that the folk art is a kind of mass art which comes from a wide spectrum of social class, especially comes from the broad laboring people. The creators of folk art are the laboring people. Therefore, the folk art is the simple art which is rooted in the masses. At the same time, generally speaking, the folk art belongs to practical art. It has more significant practical characteristics. Therefore, one of the very prominent characteristics for the core idea and the artistic style of the folk art is that it has very strong realistic color.

\subsection{The Development Present Situation of Modern Art Design in Our Country}

The development road of world modern art began in 1880. For the review of their self-growth environments and the fulfillment of social roles, human beings gradually realize that they have entered the modern society. Under the accumulation of the magnificent historical process and the abundant life elements, human beings begin to find that the art is actually a mirror which can reflect the social progress, and it is the real reflection of this world. At the same time, the society also gives the great historical mission to the art itself, and takes it as a necessary means which can promote the development and progress of human society. It can be said like this, the highly developed contemporary society and art heritage, and the cultural continuation are closely connected, and the contributions of the innovative spirit of culture and art cannot go unnoticed. At the same time, the modern art is gradually developed in the specific circumstances of human life and people's productive labor practice process. The 21st century is the era of globalization. The connection among the various countries in the world is getting more and more close, and the exchanges and cooperations among the various countries in the world are more important. Under the background of globalization era, for the modern art design we need to stand in the global perspective to survey so as to better play the function role of mutual promotion between the modern civilization and the culture and art development. The modern art design in China started relatively late. The sixties and seventies of the last century were the golden period of western industrial civilization development. At that time, our country didn't have the clear concept for the art design, mainly imitated the foreign design idea, and was still in the stage of blind western-worship. Today, although the domestic art design has developed rapidly, and the industrialization and the marketability become gradually mature. However, our country still can't fully embody Chinese characteristics. The development of modern art design can't do without innovative thinking and innovative practice of the art designers. Through the innovation, it makes the modern art be adjusted with China's current social background, cultural background and economic background to show the element tag of modern art design with Chinese cultural characteristics to the world, and embody the lofty 
sentiments of the rise of great powers. Therefore, modern art designers have a long way to go.

\section{The Reference Effect of Folk art to Modern Art Design}

Folk art originated from the Chinese land thousands years ago. After the long-term accumulation, its universality and popularity are obvious. For the folk activities which are generally carried out, among them many techniques of expression have been prevailing. In modern design activities, we can use the abstract visual elements to perform a specific affair so as to make the modern design become more persuasive. This kind of practice is also very common. In fact in the field of other art designs, the same strain of traditional technique and modern design are also everywhere.

\subsection{The Cultural Root of Folk Art}

The broad laboring people who live on hot soil are the real creation main body of folk art. The folk art is actually the crystallization and the product of the laborers' simplicity and the beauty of materialization. For this, the folk art originates from the life, originates from the laboring people and originates from the vast social heaven and earth. The laboring people not only have made their own history, and also have created the precious and priceless life wisdom and the thinking wealth which reverberate among them. Regardless of the vicissitudes of history and the baptism of time, they both can't shake the important significance for the inspiration and innovation of traditional culture to the modern society. It's even harder to erase the fact that the broad masses write the history and create the magnificent achievements of culture. Folk culture is cultivated and developed on the rich and vast land. It has a strong vitality. Every nation has its own specific artistic and cultural roots. For the reason that the local art and culture have a long history and are deep-rooted, it has created the fact that the fountain of art in our country flows always and the flower of art grows with luxuriant foliage. The Chinese art offers a rich and colorful, and brilliant and gorgeous thinking connotation for us. Firmly being rooted in the fertile land of public life and folk art is the direct reflection of its source and root. Today, the folk art has received the attention in the process of cultural trace ability and cultural-root exploration which people are keen on so as to let people increasingly attach importance to the research exploration on the folk art and let the folk art spread out more appealing artistic charm. These can produce strong excitation and inspiration power for the modern artists' creation and produce the very important influence on the artistic creators so that it is helpful to shape and cultivate the artists' interests and inspirations. Actually these have their inevitability. Because the folk art in our country is cultivated and developed on the rich and vast land. It is jointly created through the broad laboring people, and it is the inalienable important component of the Chinese nation. It inevitably affects today's art creators, at the same time, it also continues to have a significant impact on the art creators in the future.

\subsection{The Theory Contribution of Folk Art in the Process of Chinese Modern Art Development}

China is a vast country with vast territory, and numerous nationalities. It is no doubt that the art resources originated from the folk can provide rich creation materials for the modern art design. Folk art has the wide distribution on Chinese land, goes deep into the corners of the broad people's lives, and hands over from one generation to the next continuously. These rich creative materials have triggered the laboring people's and the folk art authors' imagination and creativity, and have inspired their art cells. China's modern art design must hold the attitudes of having a tribute to the folk art and take the traditional folk art as the important materials to draw the source, and comprehend the essence of folk art profoundly, and make the traditional folk art style and modern design trend converge. In this way the aesthetic original design good works with Chinese characteristics which posse the mental strategy alone and have the unique aesthetic appreciation can be created.

\section{The Practical Research of Folk Art in Modern Art Design}

\subsection{The Application of Folk Art Spiritual Connotation in the Design Creativity}

A very important basic main body content of folk art is blessing, exorcism, and reproduction. At 
the same time, the creation concept of folk art is "big, live, full, and beautiful". The so called "big", in other words, is to pursue the individuals' very big body; the so called "live", in other words, is to pursue the survival; the so called "full", in other words, is to pursue the quantity; the so called "beautiful", in other words, is to pursue the sensory comfort. The creation concept of folk art gets a lot of people's approvals, and the modern design also uses the creation concept of folk art for reference. In the process of modern design, we can "take its shape, extend its meaning, and make it be vivid and faithful".

\subsection{The Application of Folk Art Auspicious Patterns in the Graphic Design}

Auspicious patterns are an important content of folk art. Auspicious patterns of folk art include people, animals and plants. At the same time, they also include all kinds of abstract patterns. Most of them can express the auspicious implied meanings of goodfortune, emolument, longevity, double happiness, wealth and others by using table number, partial tone, implied meaning, symbol and other techniques. In folk art works, people have rich imagination and they use the abstraction, the reproductive imagination, exaggeration, allo isomorphism and other decorative techniques to express people's completion, steadiness, symmetry, satisfactory and other decorative aesthetic feelings. Folk art works leave us a lot of classic symbols. For example, "Carp jumps over the dragon gate" represents a man's success, and "people have fishes in the successive years" represents the rich life, and "The lotus has children" represents the reproduction and breeding, and there are many other examples. The modeling elements of folk art mainly reflect on two aspects. Firstly, form and structure is more exaggerated and they should pay attention to the decorativeness. Folk art works mostly serve the broad laboring people. Therefore, on the structure of form they generally cater to the tastes of social mass, and they often use the exaggerated techniques to reflect the plain and unadorned characteristics. Secondly, the modeling elements of folk art even highlight the free imagination and spatial arrangement. The creation of folk art comes from the daily life of common people, and has a high degree of freedom. The rustic emotional experience can be exuded naturally. Many groups of folk art do not necessarily depend on the objective reality of certain things, but give full play to the creators' imagination and creativity in the process of creation. They make all kinds of good things which people long for in the reality all be brought into the folk art works to express people's yearning for a better life.

\subsection{The Application of Folk art Character-drawing in Characters Design}

Chinese characters have rich implied meanings, imaginations, and even philosophies. In fact, Chinese characters are also a kind of abstract graphics with the generality. Chinese characters use semasiography, hieroglyphics, echoism, phonetic loan, synonymous characters and other elementary principles so as to make Chinese characters have strong originality and creativity. Folk art has the corresponding processing reengineering for the Chinese characters to form the symbolic form with ingenuity. In fact, there are a lot things in common among the concept of characters graphics reflected by the pictures of Chinese characters, broken stroke, stroke connection, common stroke in the process of creation and other word-formation techniques and characters design we use today. The creation techniques of folk artistic calligraphy broaden the thought of design for the characters design we use today.

\section{Conclusion}

Folk art is the important aspect of Chinese folk art. The free, romantic, lively, distinct, and flavory and graceful art forms owned by folk art represent the typical characteristics of the Chinese traditional folk culture. Folk art can use the unique artistic forms to pass the people's emotional appeals. The rich resources and concepts of folk art in our country are the precious wealth of Chinese modern art design. They can not only provide the rich nutrition for modern art design but also lay a solid foundation for Chinese high-level art design talents. At the same time, they give the significant enlightenments to promote the modern world art design to have diversified, sustained and healthy development. In the process of future art design development, the protection and inheritance of folk art resources need to be paid more attention to make the traditional style and 
modern style be combined perfectly. In this way the modern design style with Chinese characteristics which is worthy of the great era will be built.

\section{References}

[1] Lei Hongwei. The Thinking of Traditional Art and Culture Education Spread in New Countryside [J]. Art Education, 2007(4).

[2] Liu Bo. Chinese Folk Art Dictionary [M]. Beijing: Rural Reading Press, 1990.

[3] Wang Yi. Chinese Folk Art Theory [M]. Taiyuan: Shanxi Education Press, 2000.

[4] Yang Xueqin, An Qi. Introduction to Folk Art [M]. Beijing: Beijing Arts and Crafts Press, 1994: 90-235.

[5] Qian Zifen. Aesthetic Conception of Chinese Folk Art [M]. Shanghai: Shanghai Arts and Crafts Press, 1998. 